\title{
新井論文に対する論評
}

\section{Comments on Arai's Paper}

阿久津純 Jun Akutsu

ここ数年来, 北関東で発掘, 調査された星野, 岩宿, 赤堀の各遺跡の層位と, 各文化層の地質学的編年，およ びそれらの問題点について新井（1971）の論文は述べて いる. 上記の各遺跡のうち，1965年より 3 次にわたって 行われた星野遺跡の発掘調査には地質学的な立場より調 查に協力してきたので, 同遺跡の関東ローム層の層位に ついて筆者の現在の見解を述べる.

星野遺跡の第 1 次発掘の際, 第 3 地点の関東ローム層 の層序を阿久津（1966）に示してあるように区分した. すなわち,



このような判断をおこなった根拠は，地表の露頭が限 られ，トレンチ断面での観察のみで層位を決定しなけれ ばならないという制約があったが，表土下位の乱堆積層 は不規則ながら上・下に 2 分しうる特徴をもち, 上半部 には不規則塊状の鹿沼軽石層を,下半部には不規則塊状, レンズ状の赤褐色軽石層，黄色細粒軽石層を挾み，基底 部は著しく粘土化が進んでいたままた，下位の火山灰層 には暗色帯は認められず，上半部の重鉱物組成にも数\% 〜 10\%程度の角閃石を含み，基底部の軽石層の重鉱物組 成は角閃石を主とすることから真岡軽石層と判断し，上 述のような層序区分をおこなった。

その後，第 2 次 (1966年)，第 3 次（1967年）の発掘が 行なわれ，トレンチの数もふえ，層序的にもより深部ま で観察可能になった. 第 2 次発掘後, 新井によりほぼこ の論文に述べられている趣旨のことが呈示された. その 後, 第 3 次発掘の際に, 中川久夫, 新井, 阿久津で現地 調査, 討論を行ない新井の解勫の正しいことを認めた.

1.まず遺跡の数の問題がある、前期旧石器を出土す る遺跡は，芹沢によれば北関東だけでも 30 力所におよ ぶといわれるが，このような数は「北関東でいままでに 知られてきた岩宿 I 文化以降の先土器文化遺跡の総数を
すなわち，新井（1971）の本交中に詳述され，図 2 , 3，4 亿示してあるように岩相，重鉱物組成の特徴軽石 に含まれているシソ輝石の屈折率測定の結果などから， 星野遺跡の関東ローム層の層序は, 上位より

$$
\begin{aligned}
& \text { 表 土 } \\
& \text { 二次堆積層 } \\
& \text { 田原ローム } \\
& \text { 宝木ローム } \\
& \text { 宝積寺ローム (一部) }
\end{aligned}
$$

の順に累積していることになる.

表土下位の乱堆積を示す二次堆積層の形成の時期は, 第 3 地点, $\mathrm{E} ト$ トンチの田原ロームの層厚から判断して, 同ロームの堆積末期または表土堆積前と考えられる. こ の二次堆積層は山口台の南端（第 1 次発掘の第 1 トレン チ）付近まで分布し，大略その土量は $10,000 \mathrm{~m}^{3}$ に達す るものと思われる. 堆積状態より判断すると, 北東部の 後背（古生層）山地より土石流状の流出によってもたら されたものと思われるが，これらの二次堆積層のかつて 堆積していた原堆積地およびその形成機構については, まだ十分な解釈をなしえない。

資料の集積とともに新事実，新たな見解のでてくるこ とは当然のことと思われる. 地質, 考古学それぞれの立 場からの謙虚な討論と研究によって層位と文化層との問 題を明らかにしてゆきたい.

\section{引用文献}

阿久津 純 (1966) 星野遺跡の地学的研究. 星野遺跡第 1 次調查報告, 29-43.

新井房夫 (1969) 北関東の第四系. 日本の第四系, 161 171 .

(1971) 北関東口一ムと石器包含層, とくに前 期旧石器交化層の諸問題. 第四紀研究, 10, 本号. （宇都宮大学教養部地学教室）

$$
\text { 芹沢長少 }
$$

しのぐものである」から，芹沢のいう前期旧石器なるも のは疑わしい，と新井氏は考えているようである．北関 東において，岩宿 I 文化以降のすなわち上部口一ム期に 属する遺跡の数がはたして 30 カ所以下であるのかどう 
か. 群馬県遺跡地名表（尾崎編：1963）に記載されてい る上部口一ム期の遺跡は 11 力所にすぎないのであるが, 編者の尾崎氏は「今回は同氏（相沢氏）の発見調査のう ら今後の研究に差支えないもののみの発表を依頼した. したがって本書所載の遺跡は同氏発見の百分の一にも当 らない」と付記している. 言葉通りにうけとれば，群馬 県下では約 100 力所以上の遺跡がタとめられていること になるが，相沢氏の発見した上部ロ一ム期の遺跡はすく なくとも50 カ所はくだるまいと私は考えている．相沢 氏の調查以外でも, 群馬県館林市周辺からは 11 力所の 上部ローム期の遺跡が報じられており(川島：1970)，杤 木県下では同じ時期の遺跡が 26 力所 (田代 : 1966他)， 茨城県下では 14 力所名知られている (谷島: 1968他). これらを合してみれば，北関東における上部ローム期の 遺跡はこれまでに約 100 力所もしくはそれ以上が知られ ていることになる・したがって，北関東では前期旧石器 時代の遺跡数が後期旧石器時代のそれをうわまわってい るという新井氏の考えは，あきらかな間違いである.

しかしながら，筆者がしばしば書いているように，関 東地方北部の山麓斜面は, とくに前期旧石器時代の遺跡 が密集している地域と考えてよいであるう．何故なら， 古東京湾が関東平野の奥ふかく，侵入した時代にあって も，この地域には人類の居住が可能であったし，出土す る動物化石からみても人類にとってはきわめて良好な環 境であったと推定されるからである.拉なじ関東地方で も，千葉県のようなところでは，前期旧石器時代の人間 が生活できる可能性はきわめて文しかったであろうし， 北関東だけをとりあげて時代別の遺跡数を比較するのは 無意味なこころみといってよい. 関東地方全体，むしろ 日本全国の遺跡数を調査し，そのうえで前期旧石器時代 と後期旧石器時代の遺跡分布密度を考えなくてはならな いのである. そうすれば, 前期旧石器時代の遺跡数と後 期旧石器時代のそれとの間には，比較にならぬほど大き な差があるということがはっきりするであろう.

2. 星野遺跡第 3 交化層の地学上の位置については, 第 1 次報告において阿久津氏が詳細にその研究を発表し ている. その後，新井氏はこれに対して異った見解をも つに至ったようであり，本論文ではその点を力説してい る.しかし，地学上の問題はやはり地学の専門家のあい だでじっくりと討議されてしかるべきであろう．これま でも筆者は関東ローム層の地学上の問題については, 地 学の専門家の意見をつねに尊重してきたつもりであり, 一部の考古学者のように, 立川ロームは沖積世の堆積物 であって, 関東ロームの研究者は重大な誤りを犯してい
るなどというようなことは，かつて考えたこともない。 したがって，星野遺跡の地学的研究を担当されていた阿 久津氏の報告（阿久津：1966）が同氏によってさらに検 討され，将来新井氏と同じ意見に落ちついたとするなら ば，星野第 3 文化層の地学上の位置は当然改訂されなく てはならないと思う。

まえの論交（芹沢：1971）で筆者が星野第3 ·第4 交 化層の地学上の問題については, 当分のあいだペンディ ングにしておきたい，と書いておいたのは，上記の他に また考古学上の処理がからてでいるからでもある. 新井 氏のいうように，第3 文化層が再堆積であって，どこか から押し流されてきたものであるなら，第 3 文化層中の 遺物は考古学上の一時期の石器組成としては意味をもた なくなる，その中にはさまざまの時期の遺物が混在する 可能性があり，ひとつの industry とは認められなくな るのである. しかし，星野第 3 . 第 4 交化層をペンディ ングにしておいたとしても, 進展しつつある前期旧石器 の研究にはすこしの支障も生じないし，将来において旧 石器編年がある程度確立されたならば，逆に星野第 3 . 第 4 交化層の性格も考古学的に再検討されるであろう. 新井氏が言及している不器の問題については，以上の理 由からあえて言及しないでおく。

3. 岩宿ゼロ交化層および星野第 6 〜第 11 交化層か ら出土した artifactsについて，新井氏は「地質学的な 立場からみると, 石器認定に疑闑が多い」とか, 「自然 成因でも説明できるようにおもわれてならない」とか書 いている. このような問題については芹沢論交 (本号) に述べておいたので，再論するつもりはない，また，

「角䃯が現在位置まで運搬され，定着するまでには，た とえば崩落や土石流，そして匍行のくりかえしといった 複雑かつ不安定な道程をへてきたとと」によって，「無 数のチャート角礫の一部に, 原始的な石器ともみまがう ような角䃯がつくられる可能性のあることを，もっと考 慮すべきではなからうか」という新井氏の危惧について もすでに述べてある，もしも新井氏が，自然の営力によ って岩宿ゼロ交化層出土の assemblage と同様の自然 䃋が生じうるということをあくまでも主張するのなら， 任意の崖錐堆積物から $1,000 \sim 2,000$ 点のチャートの角 磷を採集してきて，その中にはたして「原始的な石器と もみまがうような角砅があるかどうか，あるとすれば全 体の何パーセントであるか，等々というような詳細を調 查のうえ発表してほしいと思う。私たちも新井氏とおな じように「冷静な視点からの基礎的研究」をつねに志向 しているからである. 


\section{引用交献}

阿久津純 (1966) 星野遺跡の地学的研究. 杤木市星野遗 跡, $29-49$.

川島正一 (1970) 関東平野西北部地域の河畔砂丘上旧不 器時代遺跡. 館林双畵, 1, 121-176.

尾崎喜左雄 (編) (1963) 群馬県の遺跡. 群馬斨教育委員 会.

1. いま, 考古学者の一部で, 前期旧石器時代といっ ているのは, 最近では, 下部旧石器時代 (Lower Palaeolithic) と, さらに中部旧石器時代 (Middle Palaeolithic) を加えたもので, 即ち新人が残した上部旧石器時 代(Upper Palaeolithic) 以前の石器時代であるらしい. たしかに，このような考光方に拉てても，その存否は 日本において重要な問題である. 例えば，わたくしなど は，そのような石器に関する遺物をまだ見ていないので ある.

ことに, 北関東地方は, それらの闍題をことさらに多 く提供している地域である.いま，ことにこの地方の地 質に詳しい新井房夫氏から，そのような問題を充分意識 しての報告を受けることは，きわめて意義のあることと いえよう.

2. 新井氏が，とくに揭げているのは, 星野・岩宿 D 地点・赤堀磯・不二山・権現山などである.それらは， 精度に多少の問題があるとしても, それぞれの資料の出 土層位について, 権現山を除いては, 地層の時代として は，大体よいであろうとしている，具体的にいえば上部 ローム層よりも下位であるとしているのである.

問題はその地層である. 星野では，それが土石流堆積 物が混入する滑落層であり, 岩宿 $\mathrm{D}$ 地点では, 古生層の チャート・砂岩・粘板岩そして石灰岩が, 後背山地の落 盤岩として，崖錐角砅層を形成し，緩斜面をつくってお り, 赤堀磯でほ, 梨木泥流堆積物がこの付近最古の火山 構成物として存在し, 下位に円碩・凝灰岩, 上位にうす

関東ローム層の発達は, 旧石器の産出層準判定や編年 に, とくべつ有利な条件を提供している. 旧石器の最初 の発見も, 関東ロームなしにはきわめて困難であったに 相違ない.

しかし，この有効な関東ローム層も，実際の露頭や現
茫沢長介 (1971) 前期旧石器の諸開㩆。第四紀研究，9, $(3 / 4), 192 \cdots 200$.

田代宽（1966）杤木県における先土器遗跡と邀物。㮵 木考古学会誌，1，2-7.

谷島静訓 (1968) 资城県西㧍よびその縁辺における旧石 器溃跡. 那珂川の先史遺跡, $2,53-79$.

(東北大学文学部考古学研究室)

$$
\text { 杉原荘留 }
$$

い角碩層が認められ，不二山では，湯ノ口軽石層より下 位ではあるが，その層位も資料発見後の認定であり，そ こでも磯と同様，泥流堆積物の上を，不整合に破砕砅を 含毛暗褐色粘士層が認められるという.

また，岩宿 D地点では，石器のよい原料となるである う桐原面の碩石を使用しないで，粗悪なチャートを用い るというのも不可解としている.

3. 以上のように, 諸地点とも角碩が自然に運搬され る地層で市って，その角砅は複雑な破硴の様子を示す可 能性があるという.

このような観察は, われわれ考古学者の, 人工のあと 学，それぞれの資料に発見するのは困難であって，自然 の破砕碩ではなからうかという考えに対し，専門家から の意見として，疑問を解消するのに大きな役割をする.

ただ，問題として残るのは，やはり権現山出土といわ れる一括遺物であって，それらが人夫の採集品であり， 当時出土層位を, 明確にしていなかったことがくやまれ る. 関東ローム層の詳細な観察ができるようになったの はその後のことであり，その時はまた発見時の露頭が失 われていたのである。

この資料は，ほとんど人工が加わっているものとして よいと, 考古学者は考えるであるう. そして, さらにそ れらは確実な出土層位別の分類ができれば，上部旧石器 時代の文化の出自についても，大きな発言ができたかも しれないと思うのである.

(明治大学文学部考古学研究室)

$$
\text { 羽 } \underset{\substack{\text { Kenzo } \\ \text { KatorI }}}{\text { 謙 }} \text { 三 }
$$

場では，一つ一つの地点ごとに，野外的諸条件がさまざ まに介入するため，どこでも確実な精度で層準識別が可 能とは限らない. 露頭の条件によっては, 鍵軽石層によ って, きわめて詳細, 高精度で信頼できる判定が可能な 場合もある. 一方，ただ単に外観的な岩相から，「何な 
にロームと思われる」ていどの，あまり得心のいかない 低い精度の判定（ことによったら全然別のローム層かも しれない）にいたるまで，いろいろの段階がある。とき としては，たのみとする鍵軽石層の判定自体が誤って， 大きな混乱を起す場合もありうる.

このようなエラ一をたはあいまいさが，なぜ，そして どのようにして起るのかという事情を知らないと, その 判定の結果を利用すべき側にとって, 地質担当者の意見 は，はなはだ頼りにならないものという印象を与えるこ ともあるわけである（その結果, 地質家の意見・判定の なかから, 考古学の立場にとって都合のいい部分だけ採 用して, 都合の悪い部分は切りすてる, という利用の仕 方に導かれなければ幸いである)，同じょうなことは植 物化石による気候編年の場合にもあてはまる，層序の再 検討をした結果，気候变化曲線を作り直さざるをえなく なった例も多く経験するところでめる.

このような例が沢山あったとしても，というょり，こ のような例が沢山あるからこそ, 石器の扱いも, 化石の 扱いと同様に，層位の優先が何にもまして基本的な大前 提となるのである.

層垃の判定精度は，それがどのていど信頼性のあるも のなのか，よほど詳細適切な記載がないと, その露頭を 扱った当事者以外にはよく分らないのが普通である．簡 単な記載の範囲では, どの資料・事実も同じ重みで信頼 するほかない，したがって評者も従来北関東の石器産出 層について，直接的経験が少なく，必ずしも充分の意見 を持合せていなかった。

評者はさいきん相沢忠洋氏らの案内で現地について見 学する 機会を得, そしてこの 新井房夫氏の 論文に接し た. 本論文における事実の綿密，周到な記載・分析と紵 括的な諸検討は，評者の認識の空所を充たすもので，同 じく関東ロームの層位研究にたずさわる一人として，そ

\section{1. はじめに}

論者（新井）は星野・赤堀磯・岩宿・不二山・権現山 など関東平野北部の前期旧石器文化遺跡における従来の 層序・石器の認定の見解に，地質学的な立場から，かな り率直な疑問を提出している.

第 1 は星野遺跡の上半部の層序に関する疑問で，彷来 と異った見解を具体的な根拠をもとにのべ，それに伴う 石器の形式学的編年の矛盾を鋭くついている. 第 2 に星 野遺跡の下部層を含めて, 多くの遺跡から出土する旧石
の扱いの行きとどいた精密さに敬服し，また共感すると ころが大きい：これによって事態の本姿はきわめて明膫 に照らしだされているといえよう。

とくに星野遺跡の缯位については，以前から同氏によ って検討されていたが，本論文では一層詳細多面的に集 約され，この層位問題の帰属についてもはや疑問の余地 がないであろう。また，最近話題に上った岩宿 9 文化を はじめとする古いタイプの旧石器の多数のものや，すで にいくつかの成畫にも引用されている不二山の遺物さ兄 も, 要検討の部類に属するととは，日本の旧石器時代に 関心ある多くの読者にとって，あるいは落胆を与えるこ とであるかもしれない.しかし，事実の基楚にたたなけ ればならない以上，それらの資料が問題を含んでいると いらことを認めないわけにはいかない，結局，立川口ー ムょり以前の文化に対しては，以前からも異論のあるこ とは聞きおよんでいたが，あるものは層位は確かだが不 器に疑義があり，またあるものは不器法確かでも層位が 不確定であり，という個々の害情が，明確な層位学的裏 付けのもとに集約整理して示されたのは，本論文がはじ めてである. 日本の中・前期旧石器時代が未確定のもの となるのは残念ではあるが，確実な事実関係から達した 結果ならばやむをえないであるう。

しかしこのことは中・前期旧石器時代の研究の価值を 損なうものでは毛頭ない. 層位学的検証が並行して進む ことによって，これらの古期の系統をより発展的に進め ることが約束されるであろう. 本論交では, 地質学的立 場からの綿密かつ良心的な, 事実に対する認定が, 考古 学と協業的に行われることこそ, いかに重要であり, 考 古学者と地質学等諸研究者との協力が, 今後一層緊密に 進められることが，考古学編年のみならず第四紀編年に もかかせないことが強調されていることを読みとるもの である。

（東京都立神代高等学校）

\section{守屋以智雄 Ichio MORIYA}

器の多くが，石器ではなく自然物ではないかという，も っとも基本的な疑問を提出している.これらは論者の綿 密な観察と分析データに基くものだけに，かなりの説得 力を持つように思われる。

評者（守屋）はこの論交の中でこまかい点で二三異論 を持つが，それは論文の結論を変えるものではない，大 すじとして論者の見解に賛意を表する.

\section{2. 星野这跡について}

1）火山灰層の同定・対比について 
星野遺跡において従来, 真岡軽石層とされていたもの は鹿沼軽石層であり，鹿沼軽石層と考えられていたもの は上部口ーム最上位に位置する三次堆積物であるという 論者の見解は重鉱物組成・紫蘇踤石の最大届折率 $\gamma \cdot$ 岩 相の観察などの結果から動かしがたいものと思われる。

論者は主に岩相と最大屈折率 $\gamma$ を同定の根拠とし, 重 鉱物組成の差を強調していないけれども，第 4 図の柱状 図 8 に示されるように, 重鉱物組成だけからも普通輝石 の有無によって, 真岡軽石層と鹿沼軽石層との判別がつ く、ただ一般的にいって，この際に注意しなければなら ないことは, 試料を軽石片だけにして類質岩片を混入し ないようにすることである. 軽石片だけとれば，その時 の噴火で放出されたマグマの重鉱物組成がそのままわか るが，既存山体の破片である類質岩片を混合すると異種 の鉱物が混入する恐れがある，例えば，真岡軽石中には， 普通輝石は存在せず, 鹿沼軽石には存在するということ で，両者を判別することができるのであるが，真岡軽石 層中に普通輝石を含えだ類質岩片が含まれていて，それ を軽石片と共にすりつぶした場合, 鹿沼軽石層と誤認し てしまうことになる，このようなことを避けるため，分 析の際にできるかぎり軽石片を洗滌して，類質岩片をと りのぞくことが必要である.しかし，ローム層の場合や 風化が進んでいる場合は類質岩片をとりのぞくことは困 難なので, その結果の解釈は慎重に行う必要がある.

以上のように，重鉱物組成だけでは同定対比に不安な 場合があるので, 論者が行ったように最大屈折率 $\gamma$ の測 定を併用するのが望ましい, 一般に鉱物の届折率測定は 非常に手間がかかるものであるが，紫蘇輝石の最大屈折 率 $\gamma$ の測定は比較的簡単に行えるし, 日本の第四紀の火 山岩の大部分は紫蘇輝石を含えでいるので, 重鉱物組成 だけでは判別のつかない火山灰の同定・対比に有効であ り，今後より活用されるべき方法であろう.

2) 火山灰層序と石器年代の矛盾について

岩相・重鉱物組成・紫蘇輝石の最大屈折率 $\gamma$ 火山灰 層の同定・対比の根拠とした論者の見解は正しいと考え ざるを得ない，とすれば，出土した石器はいずれも従来 の見解より大幅に年代が新しくなるはずである．ところ が, 出土する石器は従来の火山灰層序と矛盾しない古い 形式であるとされていた．論者の新たな火山灰層序に基 けば, 中・下部旧石器がでる層準は群馬県岩宿遺跡など では非常に新しい石器がでる層準に対比されることにな る. あまりにもこの矛盾は大きいように思える. 当時, 群馬県では上部旧石器が，杤木県下では下部旧石器が使 用されていたというのであろうか，それとも旧石器の形
式学的編年に誤りがあるのか. 火山灰層位学の精度が考 古学の精度より粗いということだけでは片ゔけられない 問題であろう.

3）二次堆積物について

直接この論文の主題とは関係ないが，遺跡の最上位層 である論者のいら二次堆積物について興味をひかれたの で若干言及してみたい。

阿久津らが宝木ローム層及び宝積寺ローム層最上部と し，論者が二次的滑落層であると考えたこの堆積物は層 状の軽石層をはさんでいて，やや乱れた構造を持ってい ると記載されている. この堆積物の岩相および，それが つくる地形についての記載がやや不明確なので詳しいこ とはわからないが, 少くとも崖錐堆積物ではないようで ある. 論者は土石流を想定しているように思われるが， 霜の作用によって緩斜面を匍行した周水河気候下の産物 である可能性はないのか, また連日の雨で水に飽和した 火山灰層がたまたま発生した大地震によって滑りだした もののようにも受けとれるが如何.

ぞのようなメカニズムで，どこから滑りだし，どのく らいの速度で, ぞの位の距離を流下したのか地学的な側 面から今後問題とされるべき堆積物であるう.

動きはじめてから止るまで, 移動速度が非常に遅い場 合, 理論的には鹿沼軽石降下後から現在まであらゆる年 代の石器がこの堆積物中に含まれてよいことになる。

\section{3. 石器の認定について}

論者は赤堀磯その他の遺跡から見出された石器が，自 然角礫ではないかという疑問を提出している，たまたま 多くの遺跡で, 石器包含層が石器によく似た角砅を多く 含む火山泥流・崖錐堆積物であったことも，このような 疑問を生じさせた原因であろう，しかし，単なる疑問で はなく, 多くの場合, 石器とされたものが自然角礫であ る可能性は非常に強いように思われる.

論者は赤堀磯などいくつかの遺跡から出土する石器が 自然角碟であると主張する中で, 権現山遺跡の石器につ いてだけは人工物であるとの見解をとっている．その主 な根拠として, 石器が硬質頁岩からなっているが, 包含 層である梨木泥流堆積物は安山岩質角碩ばかりからなっ ていて，硬質頁岩を含まないということを挙げている. しかしこの堆積物の起源と考えられる赤城火山の南〜東 斜面には，高さ $700 \sim 1,100 \mathrm{~m}$ の所に基盤岩である硬質 頁岩が露出しており，山体崩壊時にこれも混ざって流下 したことは十分に考えられ，硬質頁岩であるという理由 だけからは，自然角砂でないと断定することはできず， 権現山遺跡の石器もやはり疑問が残る. 
また「赤堀磯遺跡の層位」のところで, 論者は赤城火 山の梨木泥流堆積物は場所によって非常に岩相が異るの で何枚かに分けられる, 即ち泥流の流下が数回に分けて 行われたかも知れないと述べている. もしこれが事実な ら，その間の時期に人間が生活しえた地表面が存在し， 泥流堆積物中からも，まき込夕以外に石器がでることは 理論的に可能である. しかし, 評者の調查では, 梨木泥 流が 2 回以上にわたって流下した，という証拠は見出さ れていない. 単一の泥流の岩相が場所によって, 異るの は, 泥流が熔岩・火砕岩など種々の噴出物が積重った山 体が崩壊して流下したものと考えれば納得できる.

以上のように自然角碩を主張する論者が一歩ゆずって
石器としたものも怪しく思える. 旧石器研究はまだ石器 としたい人が見れば石器に, 石器にしたくない人が見れ ば自然物になる状況のように思われる. 研究初期の段階 では致し方ない面むあるが，このような現状を突破して 旧石器編年を確立するためには, 従来のように, 鑑定を 個人の熟練, いわゆる職人芸によっていては駄目で, 誰 で行っても同じ結果が得られる客観的な判別方法を見出 すことが必要である. そのためには論者が述べているよ らに考古学者だけでなく他の分野の協力が必要である う. 単なる水掛論に終らせてはならない.

(愛知県立大学交学部)

\section{論評に対する原著者の回答}

\section{Author's Reply to the Comments}

\section{1. 芹沢氏の論交について}

1) 北関東の前期旧石器と後期旧石器の遺跡数に関す る評者の指摘のうち, 後期旧石器遺跡数については, 論 者の認識不足が大いにあるので，考古学の側からの意見 にしたがって訂正したい，遺跡の分布密度にもとずく考 察は, 高度な考古学的・社会科学的基盤にたってはじめ てなしうるものであろう．ただし論者は，研究の進展に 応じて变動するはずの遺跡数の多寡によって, 前期旧石 器に疑問を提出しているのではない.

2 )「自然の営力によって岩宿ゼロ文化層出土のassemblage に似た自然礫が生じうると主張するなら，任意 の崖錐堆積物によって論者みずからがそれを証明すべき である」という趣旨の指摘については, 論者むそのよう な基礎的な作業が改めて必要なことを痛感している. 当 面, 地学の立場からみて好材料とおもわれるものには, 本論にものべたように, 赤堀村磯における火山泥流堆積 物中の破砕砅がある.しかし，「自然石のタイポロジー」 ともいえるこの種の検討は, 地学と考古学 (型式学) の 専門家が互に共通の基盤にたって，一体となってとりく

\section{新 井房 夫 \\ Fusao AraI}

んだとき，はじめて可能になるものと考えている。

\section{2. 守屋氏の論交について}

1）星野遺跡の二次堆積層について：この堆積物は, 指摘のような「やや乱れた構造」というよりも, 本諭に のベたように，きわめて乱れた構造をもっており，緩慢 な䈻行現象として理解することは困難である.むしろ， 十勝沖地震の際に多雨量地域に発生したような突発的な 表層滑落をおもわせる堆積物である.メカニズムについ てはよくわかっていない，類似する堆積物が星野付近か ら赤城火山南東麓の地域にかけて，みいだされてきたの で，それらもあわせて検討したい。

2）権現山遺跡の石器について：現状では指摘される ような疑問も成立しうるが, 型式学的にこれらを石器と みることについては，多くの考古学者の見解が一致して いるようである．論者はむしろみずからの層位認識に疑 問をもっている. 当遺跡は再発掘による層位確認もでき る可能性があるので，その実現を期したい.

なお，阿久津・杉原・羽鳥氏の論評に対しては，特に 述べることはない. 